Section Editor

Robert C. Griggs, MD
Editors' Note: Dr. Martinez-Ramirez et al. comment on study limitations that might have led to the authors' conclusions in "Microbleeds do not affect rate of cognitive decline in Alzheimer disease." Dr. Vanacore, in reference to "Neurodegenerative causes of death among retired National Football League players," raises the 12-fold higher risk of death from ALS in professional Italian soccer players, specifically midfielders, and calls for further cohort studies in other professional athletes.

Megan Alcauskas, MD, and Robert C. Griggs, MD

\section{MICROBLEEDS DO NOT AFFECT RATE OF COGNITIVE DECLINE IN ALZHEIMER DISEASE}

Sergi Martinez-Ramirez, Steven M. Greenberg, Anand Viswanathan, Boston: van der Vlies et al. ${ }^{1}$ found no effect of cerebral microbleeds (MBs) on the rate of cognitive decline in patients with Alzheimer disease $(\mathrm{AD})$. The same cohort previously demonstrated an association between MBs and mortality. ${ }^{2}$ Therefore, the current findings suggest that this increase in mortality was not a simple reflection of cognitive decline as measured here. However, MBs have been shown to independently affect several cognitive domains in subjects without dementia ${ }^{3,4}$ and in patients with cerebral small-vessel disease. ${ }^{5}$

Several limitations may have precluded demonstration of such effects in patients with AD: a small number of patients with lobar MBs, the use of a relatively crude measure of cognitive decline, or the overwhelming effect of $\mathrm{AD}$ pathology on cognition compared with any presumed MB-related effects.

The mechanisms by which MBs may affect cognition are still unclear. Do MBs exert their effects through direct tissue disruption or are they merely markers of accompanying cerebrovascular pathologies such as cerebral amyloid angiopathy? If MBs have direct effects on cognitive function, it is possible that specific anatomical location of MBs would have a role. ${ }^{4,5}$ Further larger studies in elderly patients with cognitive impairment may help answer some of these questions.

(C) 2013 American Academy of Neurology

1. van der Vlies AE, Goos JD, Barkhof F, Scheltens P, van der Flier WM. Microbleeds do not affect rate of cognitive decline in Alzheimer disease. Neurology 2012;79:763-769.
WriteClick: Editor's Choice

2. Henneman WJ, Sluimer JD, Cordonnier C, et al. Biomarkers of vascular damage and atrophy predicting mortality in a memory clinic population. Stroke 2009;40:492-498.

3. Poels MM, Ikram MA, van der Lugt A, et al. Cerebral microbleeds are associated with worse cognitive function: the Rotterdam Scan Study. Neurology 2012;78:326-333.

4. Werring DJ, Frazer DW, Coward LJ, et al. Cognitive dysfunction in patients with cerebral microbleeds on T2*-weighted gradient-echo MRI. Brain 2004;127(pt 10):2265-2275.

5. Viswanathan A, Godin O, Jouvent E, et al. Impact of MRI markers in subcortical vascular dementia: a multi-modal analysis in CADASIL. Neurobiol Aging 2010;31:1629-1636.

\section{NEURODEGENERATIVE CAUSES OF DEATH AMONG RETIRED NATIONAL FOOTBALL LEAGUE PLAYERS}

Nicola Vanacore, Rome: Lehman et al. ${ }^{1}$ reported an increased risk of death from amyotrophic lateral sclerosis (ALS) and AD among retired National Football League players, especially among players in speed positions. A 40-fold higher prevalence rate for ALS was reported in football players who played after $1960 .^{2}$ There was no risk of ALS in high school students who played football from 1946 to 1956, when headgear was less protective than today. ${ }^{3} \mathrm{I}$ am surprised that Lehman et al. discussed only the causal hypothesis of recurrent traumatic brain injuries or concussions whereas other possible etiologic factors were not mentioned (i.e., intense physical activity, use of drugs, exposure to neurotoxins). ${ }^{1}$ In Italy, a 12 -fold higher risk of death from ALS in professional soccer players was observed but not from AD or Parkinson disease. ${ }^{4}$ In 6 of 8 subjects, age at death was younger than 59 years. ${ }^{4}$ The risk of ALS was also significantly increased for midfielders but not for other positions. ${ }^{5}$ Lehman et al. found a different pattern of risk of death for ALS and AD vs Parkinson disease ${ }^{1}$ so this may indicate a different origin for these diseases. It might be important to know the mean age at death of players deceased from ALS and AD in this study. ${ }^{1}$ Further cohort studies in professional players of different sports should be conducted with particular attention to the position of players because this could supply important etiologic cues.

Author Response: Everett J. Lehman, Misty J. Hein, Sherry L. Baron, Christine M. Gersic, Cincinnati: We thank Dr. Vanacore for commenting on our article. ${ }^{1}$ We are aware of the important research that Vanacore and others conducted during 


\section{Neurology}

\section{Microbleeds do not affect rate of cognitive decline in Alzheimer disease \\ Sergi Martinez-Ramirez, Steven M. Greenberg and Anand Viswanathan Neurology 2013;80;1266 \\ DOI 10.1212/WNL.0b013e31828b8c16}

\section{This information is current as of March 25, 2013}

\section{Updated Information \& Services}

References

Permissions \& Licensing

Reprints including high resolution figures, can be found at: http://n.neurology.org/content/80/13/1266.1.full

This article cites 5 articles, 3 of which you can access for free at: http://n.neurology.org/content/80/13/1266.1.full\#ref-list-1

Information about reproducing this article in parts (figures,tables) or in its entirety can be found online at:

http://www.neurology.org/about/about_the_journal\#permissions

Information about ordering reprints can be found online:

http://n.neurology.org/subscribers/advertise

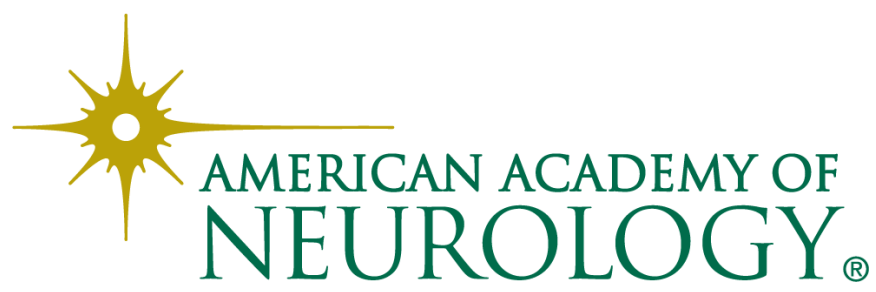

